\title{
Environmental and Economic Impact of Employing Solar Chimney and Photovoltaic Cells in Buildings with Various Climates
}

\author{
Mohammad Hossein Jahangir ${ }^{*}$, Seyed Keyvan Nateghi \\ Faculty of New Sciences and Technologies, University of Tehran, Iran \\ E-mail: mh.jahangir@ut.ac.ir
}

Received: 7 June 2021; Revised: 19 July 2021; Accepted: 27 July 2021

\begin{abstract}
In this research, Solar Chimney (SC) as a passive system in the building, is used to provide thermal comfort and reduction of energy consumption. The operation of SC will have different effects in different climates. Investigating this issue can make it possible to use this system in places where its operation is more efficient in terms of thermal comfort and economic issues. EnergyPlus was applied to model a house with SC. Potential of cooling and heating generated by SC was investigated in Humid (Babol) and Semi-arid (Tehran) climates. The result shows that in Babol, SC saves approximately $21 \%$ in cooling load and $16 \%$ in heating load consumption. On the other hand, in Tehran, using SC can save $35 \%$ in cooling load and $20 \%$ in heating load consumption. For both humid and semi-humid climates, Summer-SC (ventilation mode) performs better than Winter-SC (heating mode). In continue, for each city, the cost of saving electricity consumption by SC was spent on the purchase and installation of photovoltaic cells (PV). According to calculations, SC and PV systems annually produce $4717 \mathrm{kWh}$ of clean energy in Babol and $6965 \mathrm{kWh}$ in Tehran. In addition to producing clean energy, despite the low cost of grid electricity in Iran, employing these systems in each house, annually reduces the cost of electricity consumption by $\$ 8$ and $\$ 14$, respectively, in the cities of Babol and Tehran. Of course, this amount would be considerable for all the houses in a city.
\end{abstract}

Keywords: solar chimney, photovoltaic cells, EnergyPlus, renewable energy sources, green building

\section{Nomenclature}

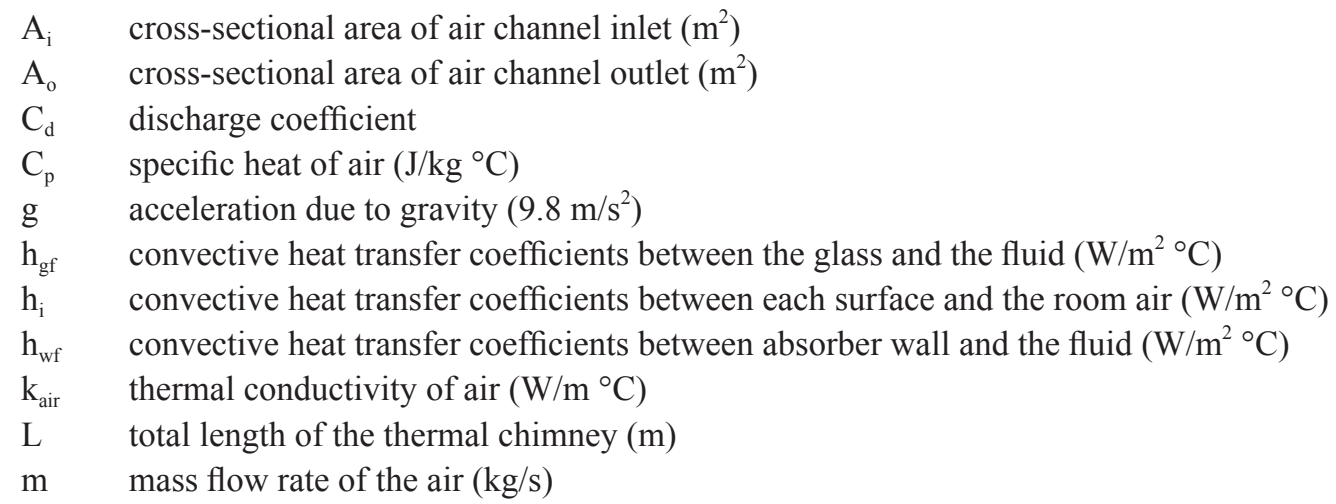

Copyright (C2021 Mohammad Hossein Jahangir, et al.

DOI: https://doi.org/10.37256/aecm.222021979

This is an open-access article distributed under a CC BY license

(Creative Commons Attribution 4.0 International License)

https://creativecommons.org/licenses/by/4.0/ 


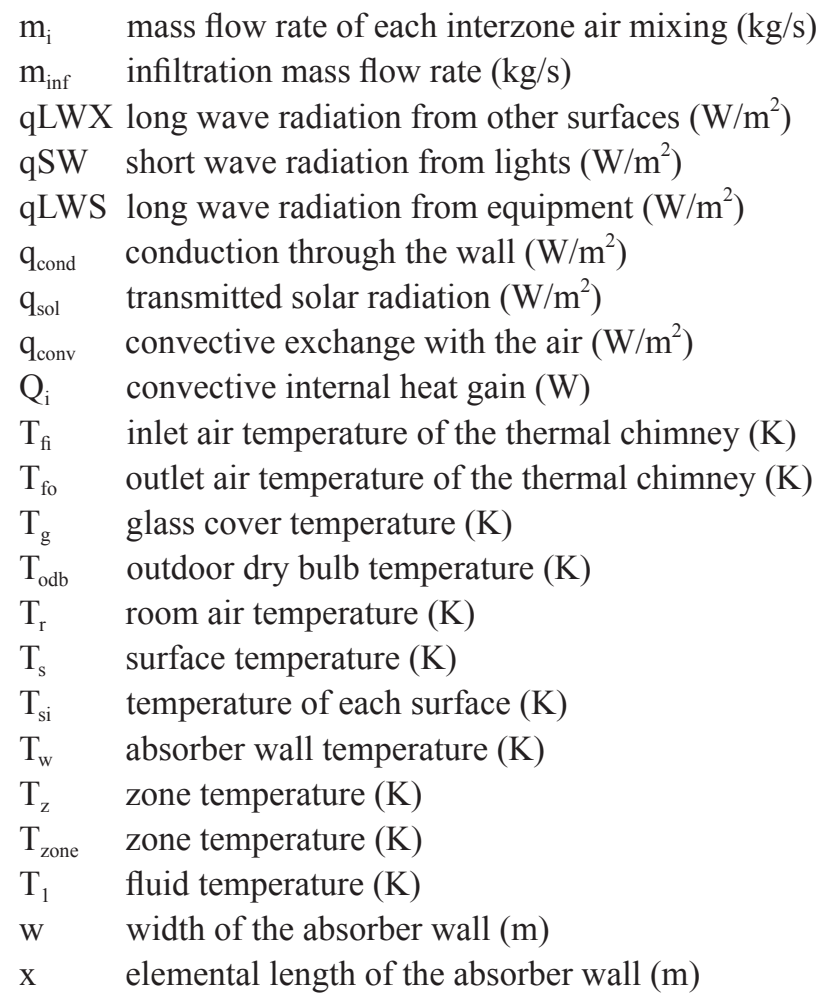

\section{Introduction}

Energy consumption in the building is an important factor in the total energy consumption of every country [1]. With increasing energy demand and greenhouse effect, energy in buildings and the environment have become major issues all around the world [2]. The main strategies to reduce $\mathrm{CO}_{2}$ emissions include increasing the use of renewable energy sources [3]. Among renewable energies, solar energy is the largest potential renewable energy [4]. Researchers figured out how to use Solar Chimney (SC) to provide ventilation inside buildings or to heat and even cool the buildings [5]. SC is an important system in passive design to use solar energy. This system can be used to achieve adequate airflow and desired level of thermal comfort inside the building [6]. SC can be divided into two models: Winter SC, and Summer SC. In winter, when the outdoor temperature is below a specified amount, SC automatically shuts off to prevent over-cooling of the building, which may be caused by improved air-conditioning. In a different circumstance, in summer, while the outside temperature rises above a certain value, SC is spontaneously deactivated to prevent the air zone from overheating. The outlet of SC opens into the house in winter and into the open air in summer to provide ventilation. Two main types of operation of SC are shown in Figure 1. As described in Figure 1, when a winter SC is used for passive heating operation, airflow is warmed by the absorber facade, and then hot air enters the zone. SC can work in natural ventilation way or passive cooling meanwhile the cooling load is needed, and the outdoor temperature is lower than the indoor temperature. The study on SC started in 1993 and has continued to still now.

The first studies in the field of SC were conducted in 1993 by Bansal et al. [7]. They proved the increase in ventilation by using SC and the correct design of a permanent system through a mathematical model. Hirunlabh et al. [8] also studied different types of SC and concluded that SC is effective in ventilation and airflow. Sudaporn and Bundit [9] experimentally investigated the effect of an SC on increasing indoor air conditioning in the presence or absence of a wet roof and concluded that the external SC, depending on the ambient temperature and the amount of solar radiation, can reduce the indoor temperature 1 to $9 / 5$ degrees. Oliveira has confirmed the effect of solar energy on increasing ventilation by comparing SC with a conventional chimney. Burek and Habed [10] perform an experimental system to relate the air mass flow rate and heating efficiency by varying the heat inlet and channel depth in a test model similar to a vertical solar chimney. Imran et al. [11] studied experimentally and numerically the performance of SC under various 
geometrical dimensions in Iraq. In these studies, the solar chimney of $2 \mathrm{~m}$ height, $2 \mathrm{~m}$ width, and three gap thicknesses $(50,100$, and $150 \mathrm{~mm})$ was accommodated to the roof of a room with a bulk of $12 \mathrm{~m}^{3}$. The numerical experiments picked that the optimized chimney slope angle was $60^{\circ}$ to get the maximum rate of ventilation. Bassiouny and Korah [12] studied numerically the effect of the vertical chimney width on space ventilation. They derived that enhancing the width of the chimney from $0.1 \mathrm{~m}$ to $0.3 \mathrm{~m}$ increases the volume airflow rate by approximately $25 \%$, maintaining the chimney inlet size fixed.

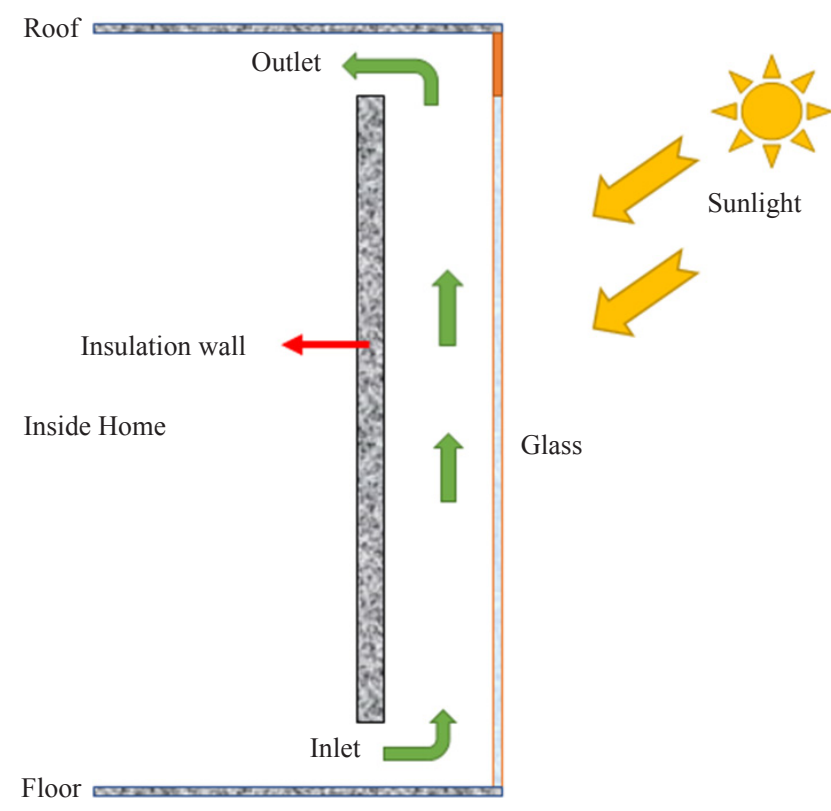

(a)

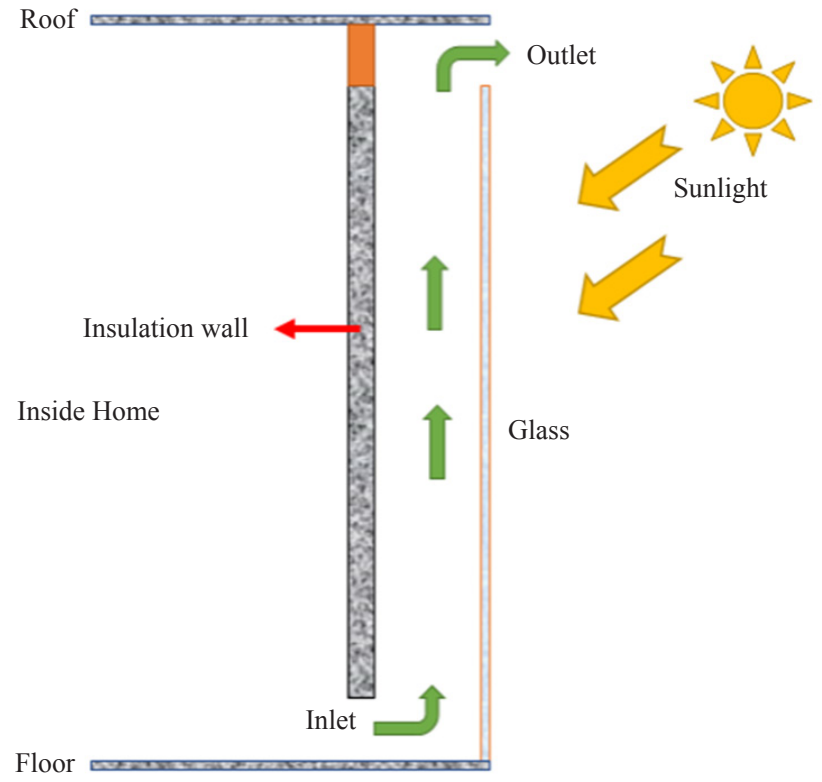

(b)

Figure 1. Two main types of solar chimney's operation: Winter SC-Passive heating mode (a), Summer SC-Natural ventilation and cooling mode (b)

Recently, Sudprasert et al. measured the effect of humid air on the performance of a vertical SC. The computational results of air velocity and temperature distribution in dry air chimneys were compared with the results of humid air in both cases with uniform chimney wall temperature. Compared to dry air solar chimneys, the airflow efficiency was 26.2\% lower and the overall air temperature was higher for a humid air chimney [13]. Lechowska et al. [14] measured the 24-hour performance of a rooftop SC in 12, Poland (a hot, sunny day). The researchers performed the simulations for three different thicknesses of 10,20 , and $30 \mathrm{~cm}$. The results showed that the solar chimney with the narrowest absorber $(10 \mathrm{~cm})$ was the most efficient. The adsorbent is heated to the highest temperature up to $82^{\circ} \mathrm{C}$. It also emits the most heat during the night, creating the highest airflow through the chimney at 3,820 cubic meters in 12 hours, meaning the building is more ventilated. The thicker adsorbents $(20 \mathrm{~cm}$ and $30 \mathrm{~cm})$ heat up slowly and accumulate less heat. All research has been used for transient modeling of solar chimneys from commercial CFD software.

$\mathrm{SC}$ reduces the heating and cooling load on the building. The thermal efficiency of a passive ventilation system with SC on resident's thermal comfort in Hot-Arid climate (Egypt) was investigated by Abdallah [15]. Finally, when outdoor temperature above $42^{\circ} \mathrm{C}$ residents continued satisfied in the range of $-0.5<\mathrm{PMV}<+0.5$. A quasi-stationary three-dimensional CFD model was measured using a new optimization method to improve indoor resident comfort by enhancing air velocity due to the effects of buoyancy in the area by Abdeen et al. [16]. The result was that SC with a width of 2.65 meters, a height of 1.85 meters, an air gap of 0.28 meters, and a slope angle of 75 degrees, increases thermal comfort under the intensity of the sun by more than 500 watts per square meter. The cost of saving electricity from using SC, in the long run, can be spent on buying photovoltaic cells. Photovoltaic cells have a long life and low maintenance costs and can provide part of the electricity needed by the building. Therefore, employing solar chimneys and photovoltaic cells in buildings can be both environmentally and economically beneficial. But the performance of 
these two systems will be different in different climates. In this study, these solar systems were used for a house in two different climates and the results were compared.

\section{Problem formulation and numerical method}

\subsection{Governing equations}

"EnergyPlus" is used to simulate the SC model. SC model was created separately and added to the model in EneryPlus. This module is performed in the heat balancing section to compute the effect of boosting the air penetration rate created by SC in indoor heat balancing. Because in EnergyPlus, the penetration part is located in the air heat balance part. Indoor heat balancing in the software of EnergyPlus spontaneously includes all indoor loads, heat transfer as a result of penetration, heat transfer by cause of combining of air in nearby areas, and energy supplied by air conditioning system in the following order. Becomes [17]:

$$
\begin{gathered}
\sum_{i=1}^{N_{i}} Q_{i}+\sum_{i=1}^{N_{\text {surface }}} h_{i} A_{i}\left(T_{s i}-T_{z}\right)+\sum_{i=1}^{N_{\text {zones }}} m_{i} C_{p}\left(T_{z i}-T_{z}\right)+ \\
m_{\text {inf }} C_{p}\left(T_{\infty}-T_{z}\right)+m_{s y s} C_{p}\left(T_{\text {sup }}-T_{z}\right)=0
\end{gathered}
$$

Where $Q_{i}$ is the heat gain (W), $h_{i}$ is convective heat transfer coefficients between each surface and the room air $\left(\mathrm{W} / \mathrm{m}^{2}{ }^{\circ} \mathrm{C}\right), A_{i}$ is the cross-sectional area of air channel inlet $\left(\mathrm{m}^{2}\right), T_{s i}$ is the temperature of each surface $(\mathrm{K}), T_{z}$ is zone temperature (K), $C_{p}$ is the specific heat of the air $\left(\mathrm{J} / \mathrm{kg}{ }^{\circ} \mathrm{C}\right), m_{i}$ is the mass flow rate of each interzone air mixing $(\mathrm{kg} / \mathrm{s})$ and $m_{\text {inf }}$ is infiltration mass flow rate $(\mathrm{kg} / \mathrm{s})$.

Due to the complexity of the phenomena inside the SC, some simplifying assumptions were adopted as follows:

- There is no temperature change in the surface of SC components; By way of explanation, in these components, heat transfer is supposed to be one-dimensional.

- The temperature of the air at the entrance to air in SC is similar to the air zone.

- Because of surface friction, the resistance of airflow can be neglected.

- The discharged air through the SC to the outside is replaced by an equal amount of air to the outside circumstances.

The main output parameter in the SC is the rate of improvement of passive air conditioning due to the presence of a chimney. To ascertain the improvement of air-conditioning, the air temperature leaving the SC must be calculated, which is also obtained based on information such as the perpendicular temperature dispensation, the glass cover temperature, and the absorber wall temperature inside SC. From the above, the surface thermal balance for the glass cover and absorber wall is extracted by the algorithm in EnergyPlus software. The vertical temperature distribution and the temperature of the air discharged from the SC are calculated using a separate heat chimney algorithm. According to the temperature data of the wall absorber, glass, and coefficients of the heat transfer calculated in the software, the thermal equilibrium for the air inward the $\mathrm{SC}$ is shown as follows:

$$
h_{w f}\left(T_{w}-T_{f}\right)=h_{g f}\left(T_{f}-T_{g}\right)+\frac{\dot{m} C_{p}}{w} \frac{d T_{f}}{d x}
$$

Information about the symbols and the necessary instructions for the above equation is given in the nomenclature. Given the initial conditions in Equation (2), the following equation is obtained for use in the finite difference method:

$$
h_{w f}\left(T_{w}-\frac{T_{n+1}-T_{n}}{2}\right)=h_{g f}\left(\frac{T_{n+1}+T_{n}}{2}-T_{g}\right)+\frac{m C_{p}}{w} \frac{T_{n+1}-T_{n}}{\Delta x}
$$

In this method, the area inside the SC is divided into several sub-areas. In the above relation, $T_{n}$ and $T_{n+1}$ represent 
respectively the air temperature in the sub-areas $n$ and $n+1$ inside the air duct. The size of the absorber wall in every sub-area showed with $\Delta x$. According to the temperature of the outlet air calculated by the finite difference method $\left(T_{f o}\right)$, the volumetric flow rate of the airflow inside $\mathrm{SC}, Q\left(\mathrm{~m}^{3} / \mathrm{s}\right)$ is calculated from the following equation:

$$
\begin{gathered}
Q=C_{d} A_{o} \sqrt{\frac{2\left(\frac{T_{f o}-T_{r}}{T_{r}}\right) g l}{\left(1+A_{r}\right)^{2}}} \\
A_{r}=\frac{A_{o}}{A_{i}}
\end{gathered}
$$

In the above equations, $T_{f o}$ refers to the temperature of the air in the outlet $(\mathrm{K}), C_{d}$, discharge coefficient, $L$, the total size of the SC, $A_{o}$ and $A_{i}$, the cross-section of the air duct at the outlet and inlet $\left(\mathrm{m}^{2}\right)$ and, $T_{r}$ is the temperature of the indoor $(\mathrm{K})$. As mentioned, the amount of air evacuated from the inside is replaced by outside air by the heating SC. The thermal air balance management section in the software is configured to implement a separate SC module in a way that corrects the infiltration rate of air improved by the SC. Since the air infiltration is also modeled in the same part of the software, this SC spontaneously raises the penetration rate to the extent that it is responsible for both the amount of infiltration set by the user and that of ventilation by the SC. Finally, the amount of heat lost and absorbed from each area is determined by the heating chimney with the following equations:

$$
\begin{aligned}
& Q_{\text {gain }}=m C_{p}\left(T_{\text {zone }}-T_{\text {odb }}\right) \\
& Q_{\text {gain }}=m C_{p}\left(T_{\text {odb }}-T_{\text {zone }}\right)
\end{aligned}
$$

Where $T_{\text {zone }}$ and $T_{\text {odb }}$ are the temperatures of the dry bubble outside and the desired area, respectively. The amount of heat lost and absorbed is also available in the thermal balance section of the EnergyPlus software to calculate the changes in indoor air temperature due to the heating chimney. EnergyPlus software also considers the latent effects of the SC in the moisture balance section [18].

\subsection{Model specifications}

As mentioned in this research, a model simulated in EnergyPlus automatically takes into account all equations related to surface, heat, energy and air in the total building. In addition to the proposed algorithm, air and heat exchange between adjacent environments, solar radiation from transparent building surfaces, electrical equipment and lighting, absorption of indoor heat from people, and transient conduction of heat from the building shell concurrently to simulate SC performance. These also include the conduction heat exchanged between the space and the absorber wall, and the absorber wall temperature of the SC. The effects of air infiltration in the SC are taken into account in calculating the absorber wall temperature and the amount of conductive heat transfer from the walls.

The designed building area is approximately $250 \mathrm{~m}^{2}$ with a height of 3 meters. For the maximum solar radiation absorption, SC is connected to the south side of the building. The plan designed in AutoCAD software for the assumed house is also shown in Figure 2. Figure 3 shows the two north and south views of the building designed in SketchUp software. The internal heat of the equipment and lights is set at $4.5 \mathrm{~W} / \mathrm{m}^{2}$. For metabolic rate, two people are considered in the house through simulation (All hours of the day). One in the living room and the other in one of the bedrooms. Information on indoor air velocity, indoor air temperature, and clothing insulation level is shown in Table 1. Also, by referring to Table 2, the complete specifications of the materials used in the building can be seen. For dimensions of SC, since SC completely covers the south wall of the house, the dimensions of SC will be the same as those of the south wall. 


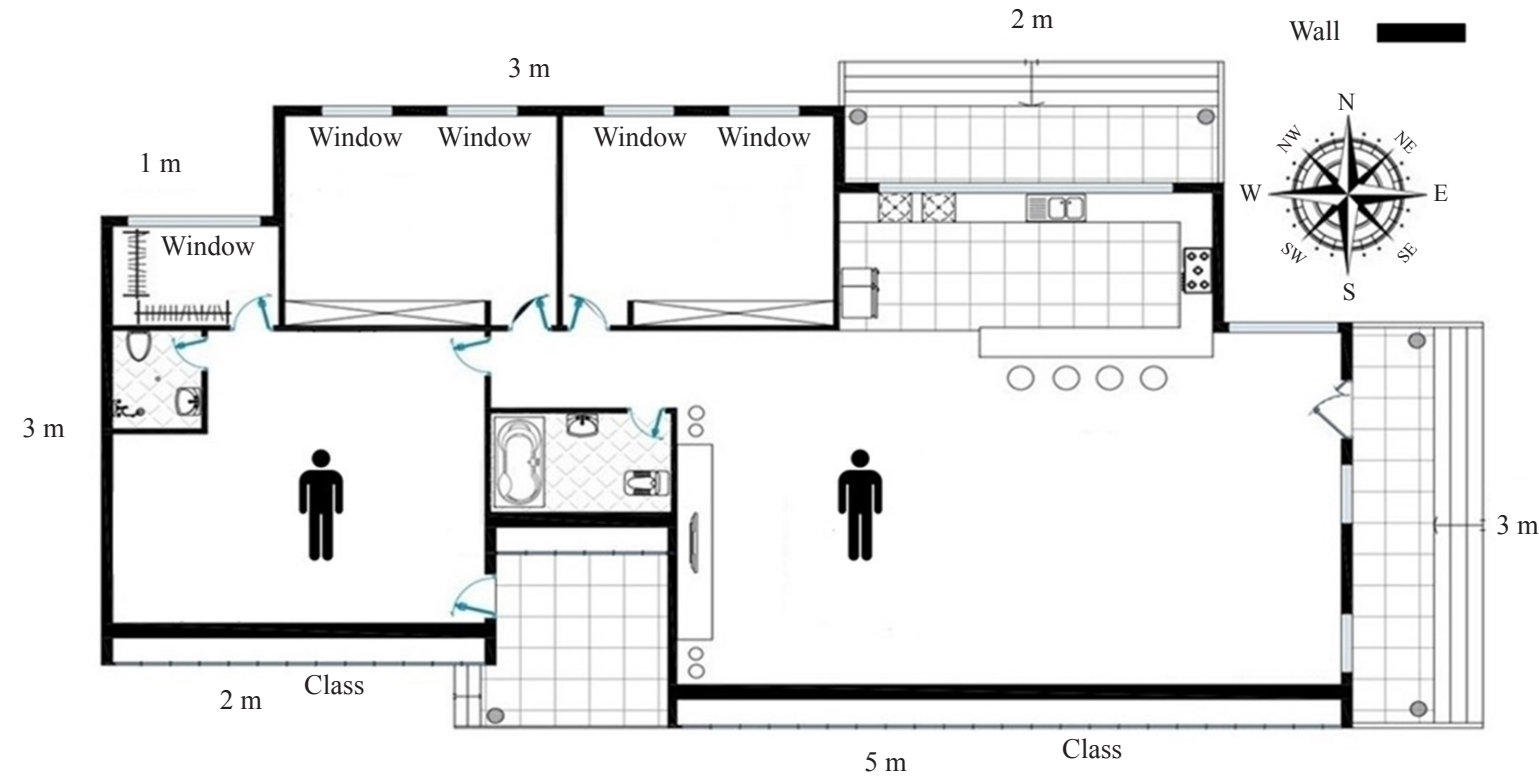

Figure 2. House plan designed in AutoCAD software
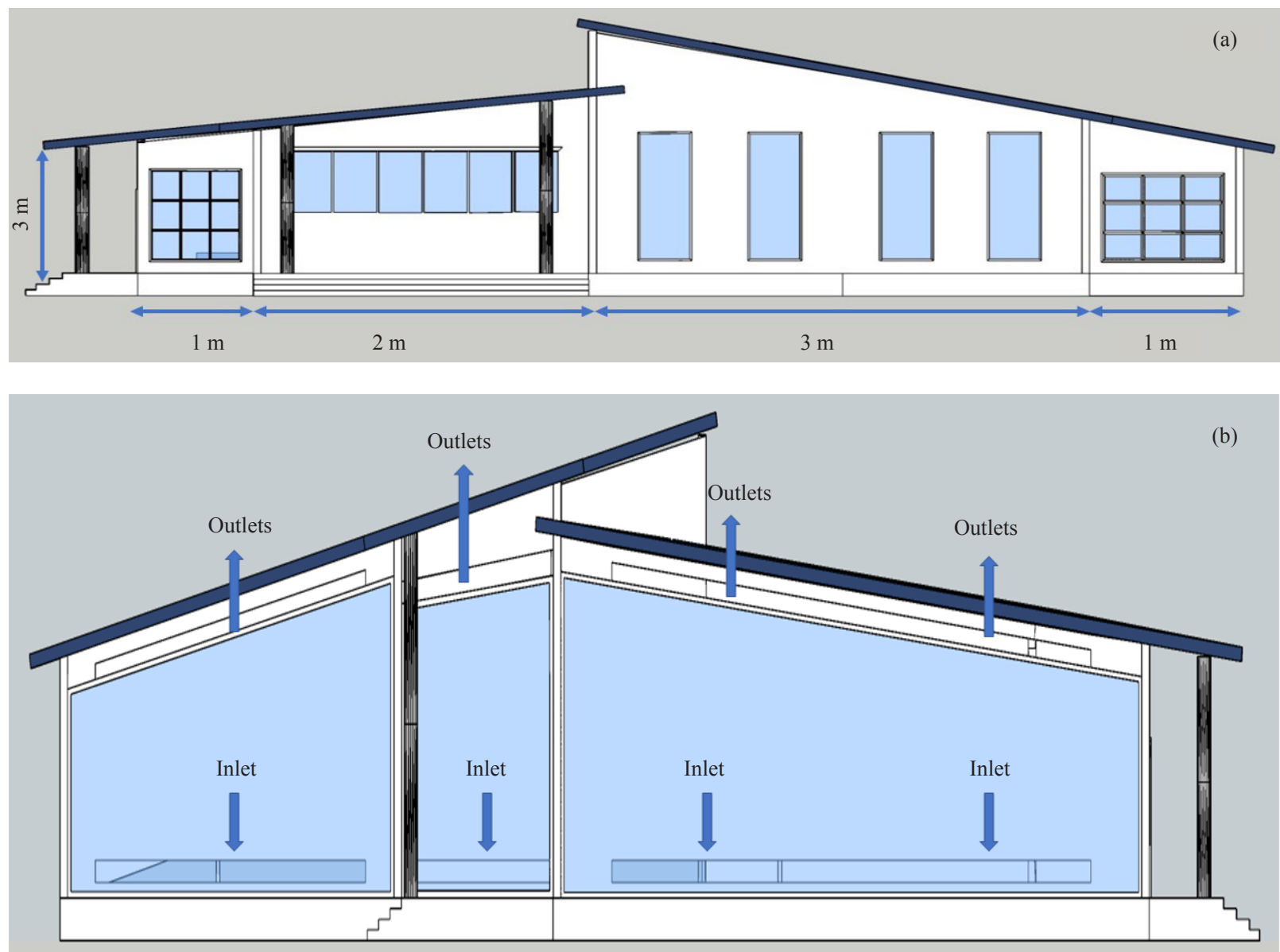

Figure 3. North view of the house designed in EnergyPlus, including walls and windows (a), South view of the house designed in EnergyPlus, which shows the solar chimney-The outside of the chimney is completely covered with glass to absorb most of the sunlight (b) 
Table 1. Parameters set in EnergyPlus

\begin{tabular}{ccc}
\hline Parameters & Winter & Summer \\
\hline Indoor air velocity $(\mathrm{m} / \mathrm{s})$ & 0.2 & 0.5 \\
Indoor air temperature $\left({ }^{\circ} \mathrm{C}\right)$ & 25 & 21 \\
Clothing insulation level & 1 & 0.5 \\
\hline
\end{tabular}

Table 2. Thermal specifications of the construction materials

\begin{tabular}{ccccc}
\hline Material & $\begin{array}{c}\text { Solar } \\
\text { absorptance }\end{array}$ & $\begin{array}{c}\text { Specific heat } \\
(\mathrm{J} / \mathrm{kg} \mathrm{K})\end{array}$ & $\begin{array}{c}\text { Thermal conductivity } \\
(\mathrm{W} / \mathrm{m} \mathrm{K})\end{array}$ & $\begin{array}{c}\text { Density } \\
\left(\mathrm{kg} / \mathrm{m}^{3}\right)\end{array}$ \\
\hline Metal surface & 0.7 & 418 & 45 & 7824 \\
Room's wall & 0.7 & 900 & $0 / 89$ & 2050 \\
Chimney's wall & 0.92 & 900 & 1.95 & 2240 \\
Insulation board & 0.1 & 1210 & 0.03 & 43 \\
Brick wall (100 mm) & 0.1 & 790 & 0.89 & 1920 \\
Gypsum board (20 mm) & 0.1 & 1090 & 0.16 & 800 \\
Metal door & 0.5 & 418 & 45 & 7680 \\
Mosaic & 0.5 & 790 & 1.8 & 2560 \\
Cement board & 0.1 & 1000 & 0.58 & 1900 \\
Stone tiles & 0.1 & 790 & 3.17 & 2560 \\
\hline
\end{tabular}

\section{Results and discussion}

Building designed by SC simulated to investigate the heating and cooling potential. Two similar constructions, one with SC and the other without SC, were assumed simultaneously and, the rest of the conditions were considered the same for both. The amount of reduction of cooling and heating load by using SC depends on weather conditions. This reduction varies from one geographical location to another. To evaluate the efficiency of SC, annual simulations were done for two humid and semi-arid climates in the presence or absence of SC.

\subsection{Numerical solution validation of Energyplus model}

To validate the research, a solar chimney model was designed in EnergyPlus according to a previous experimental study and the results were compared with the experimental data obtained by Arc et al. [20,21]. SC model was implemented using a concrete wall to provoke night airflow as a result of thermal immobility in the absorber wall. Experimental data have been collected from the Tabernas desert in the Almeria (Spain), identified by Hot-Humid climates. The position of the experimental model is completely independent and has two equal openings, one at the top and the other at the bottom. Its absorbent wall also has dimensions of $0.15,0.3$, and 1 for its thickness, depth, and width, respectively. Details were defined in EnergyPlus. Three main factors containing airflow velocity, exhaust air temperature, and absorber temperature were selected for days sequentially 15th September, 9th October, and 28th December. Results compared with experimental data obtained from [19] to validate the simulated results. According to Figure 4, there is a sensible correlation between the measured and simulated adsorbent temperature on October 9 between $5 \mathrm{AM}$ and $9 \mathrm{PM}$, according to the reference. 


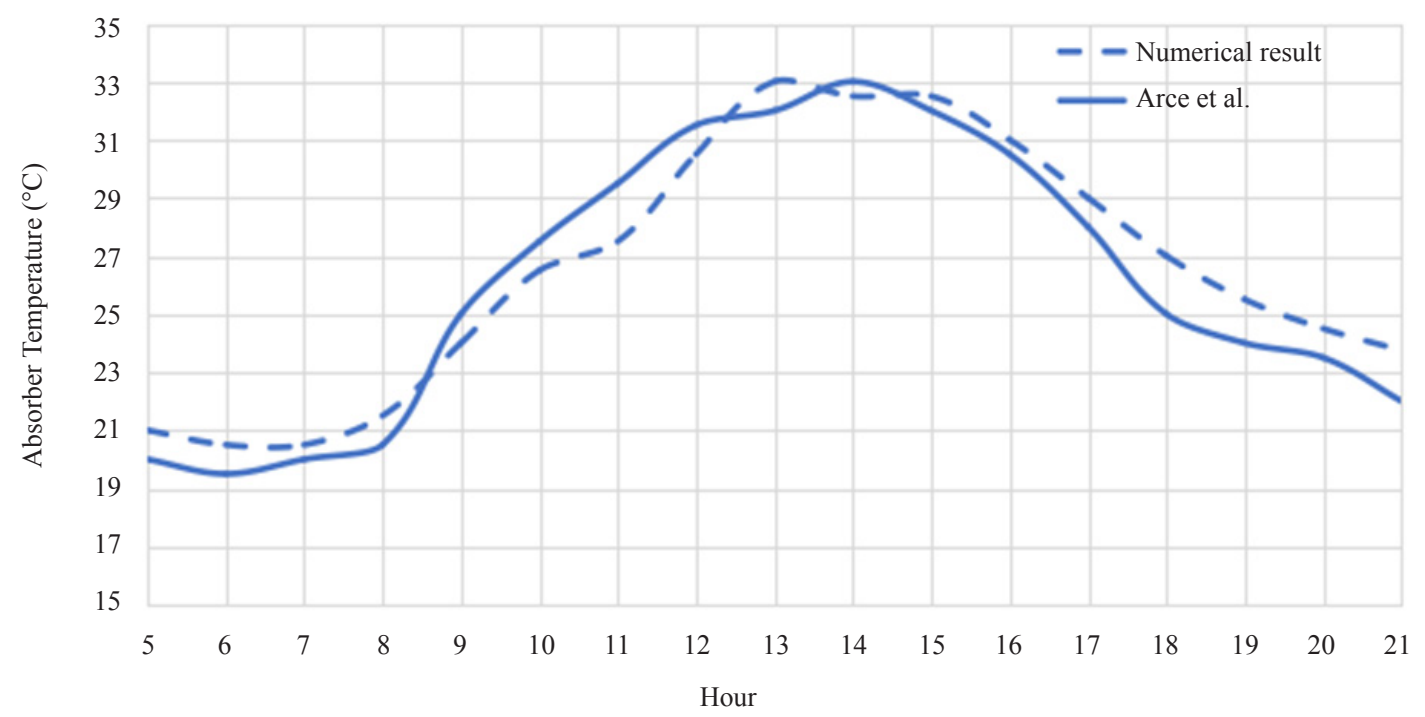

Figure 4. Comparison of solar chimney absorber temperature on October 9 between experimental results from reference [18] and simulated

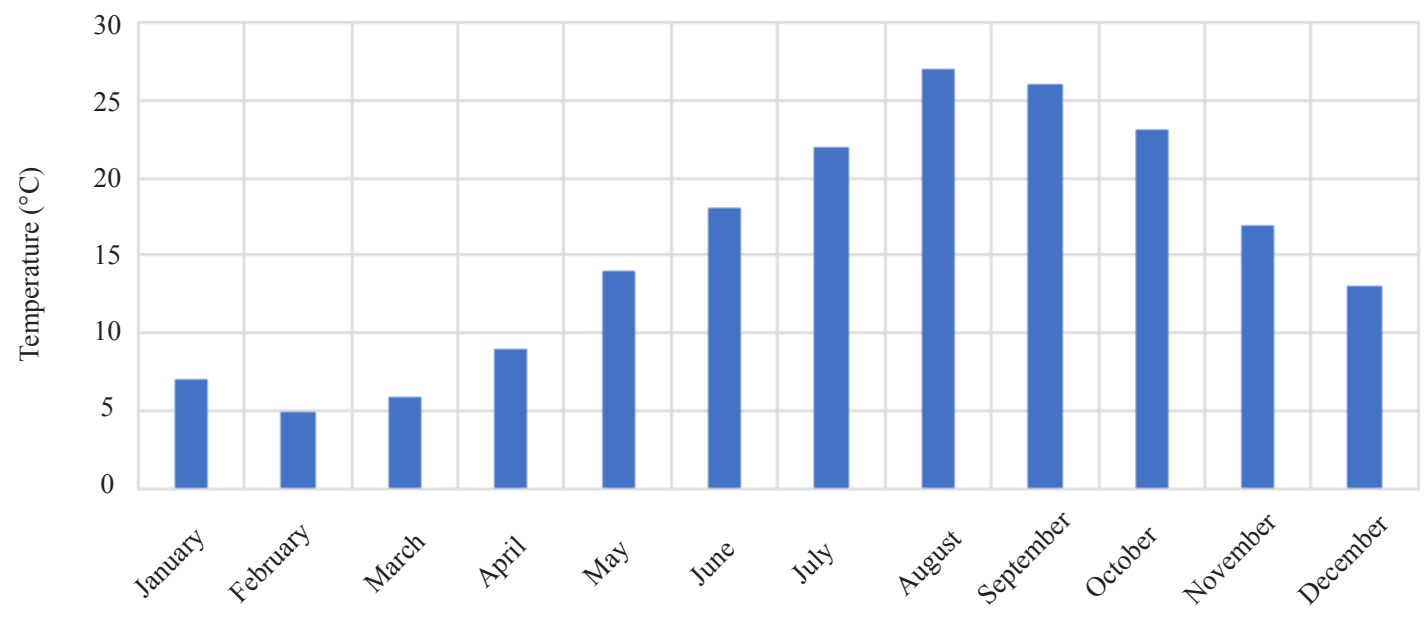

(a)

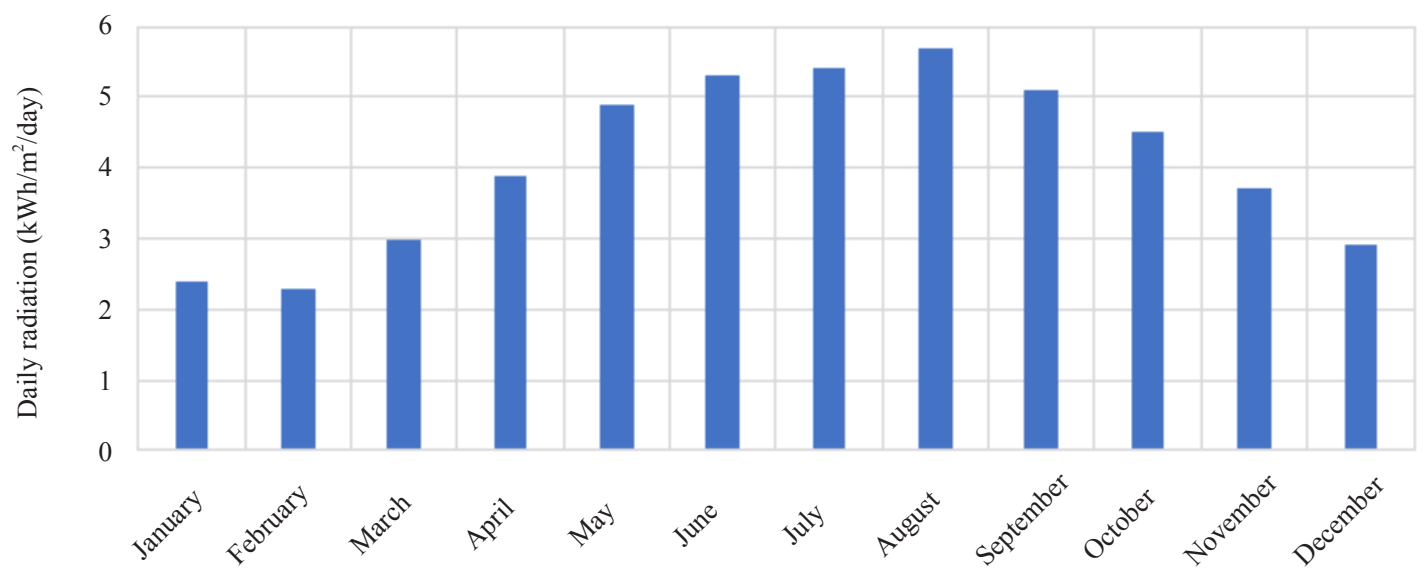

(b)

Figure 5. Average annual Temperature (a) and Radiation (b) in Babol 


\subsection{Investigation of cooling and heating load in Humid climate (Babol)}

Babol was selected for investigating cooling and heating load in Humid climates. The height of this city is about 2 meters lower than the sea level. Babol is located between 36 degrees and 34 minutes and 15 seconds north latitude and 52 degrees and 44 minutes and 20 seconds East longitude of the Greenwich meridian. Babol has hot and humid summers and cold and relatively humid winters. The average temperature and amount of solar radiation each month of the year based on measurements for 20 consecutive years (1990-2010) are shown in Figure 5 [22]. Graph of average relative humidity every month in Babol can be seen in Figure 6. It is natural that with increasing solar radiation, SC affects heating and cooling load. But the amount of this effect will be different in different climates. Solar radiation and open-air temperatures follow a similar pattern. This amount peaks in August and reaches its lowest level in February. When the open-air temperature is higher than the standard room temperature, Summer-SC is needed and on the other hand, when the temperature is lower than the standard room temperature, Winter-SC is needed. As can be seen in Figure 7, cooling or heating load consumption is calculated in terms of kilowatt-hours in "Without SC" and "With SC" modes. In summer, when the humidity is very high, SC has less effect on reducing load consumption. But in months like November or May when the weather is mild, SC has had a great impact. The hours of light and sunlight have also been effective in the impact of SC in winter. Table 3 shows how much energy is saved each month of the year by using SC. From May to November, due to the high temperature, Summer-SC is needed. During other months, the vent to the outdoors closes, and the top vent to inside the house opens (Winter-SC). The best month to use SC is May. Table 4 shows that in total, approximately $21 \%$ of the cooling load was saved annually by using the Summer-SC to reduce the required cooling load. This amount was approximately $16 \%$ for the heating load, which was lower than the cooling load. Therefore, Summer-SC will be relatively more efficient than the Winter-SC in a Hot-Humid climate.

Table 3. Energy saved by month-Hot-Humid (Babol)

\begin{tabular}{ccc}
\hline Month & SC Type & Percentage of energy saved \\
\hline January & Winter SC & 7 \\
February & Winter SC & 5 \\
March & Winter SC & 17 \\
April & Winter SC & 41 \\
May & Summer SC & 61 \\
June & Summer SC & 47 \\
July & Summer SC & 11 \\
August & Summer SC & 2.8 \\
September & Summer SC & 3.5 \\
October & Summer SC & 14 \\
November & Summer SC & 59 \\
December & Winter SC & 24 \\
\hline
\end{tabular}

Table 4. Annual consumption load-Hot-Humid (Babol)

\begin{tabular}{ccc}
\hline$\#$ & Annual cooling load requirement $(\mathrm{kWh})$ & Annual heating load requirement $(\mathrm{kWh})$ \\
\hline With SC & 8,674 & 5,507 \\
Without SC & 10,954 & 6,608 \\
Percentage of energy saved & $21 \%$ & $16 \%$ \\
\hline
\end{tabular}




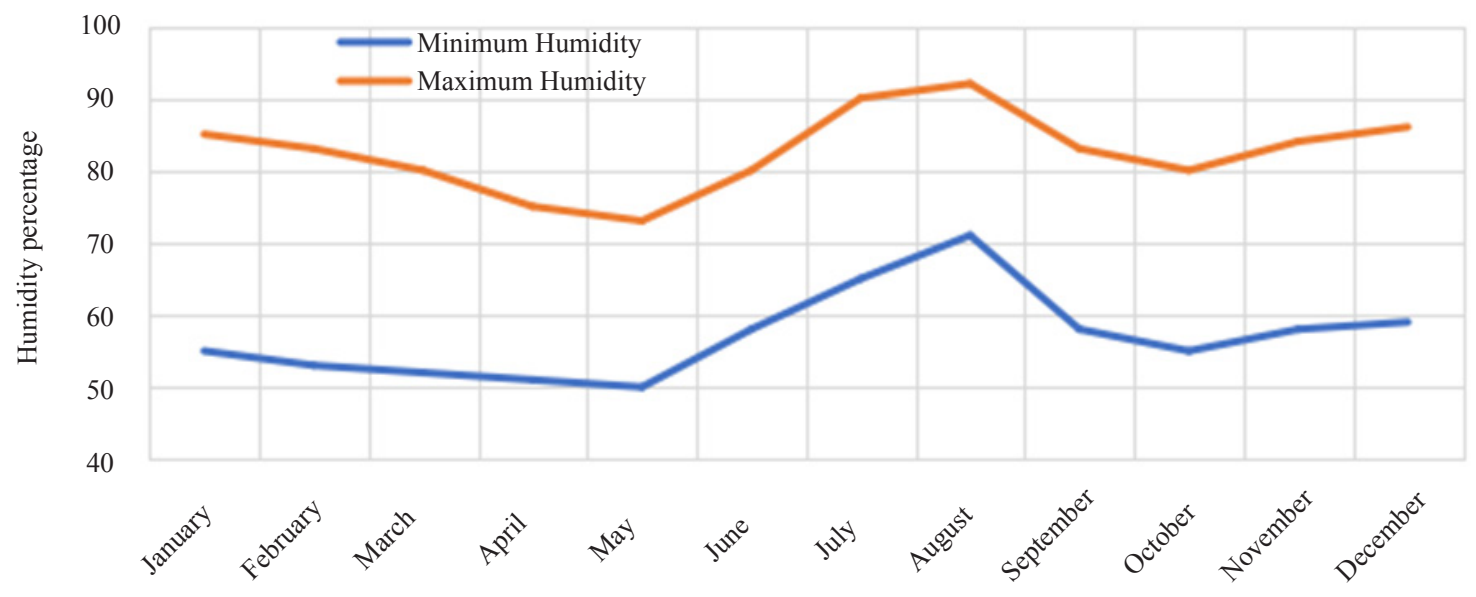

Figure 6. Graph of average relative humidity every month in Babol [23]

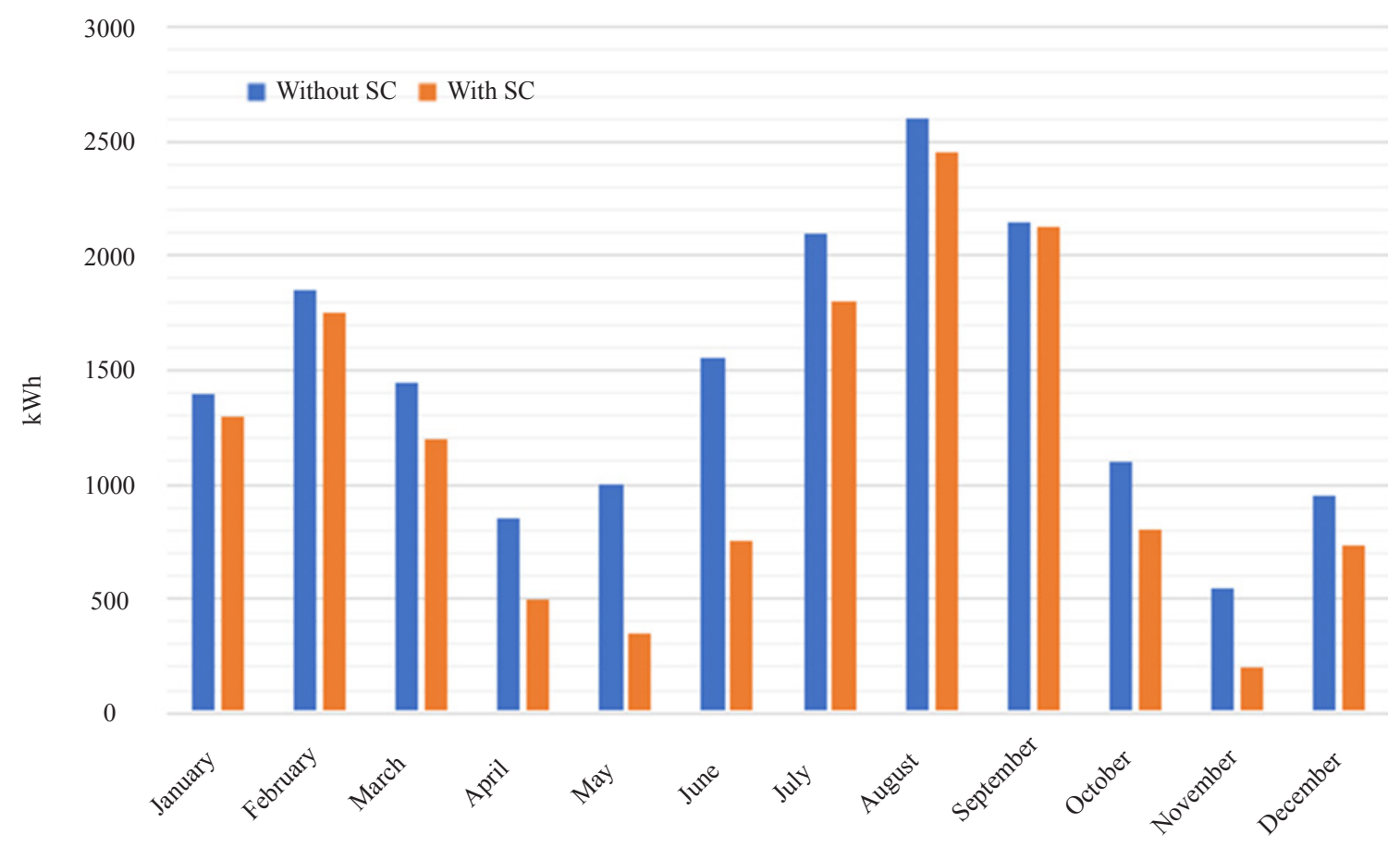

Figure 7. The amount of annual energy consumption in conditions with and without solar chimney for the city of Babol

\subsection{Investigation of cooling and heating load in semi-arid climate (Tehran)}

Tehran is a big city and has a semi-arid climate. The north of the city is often cooler than other parts due to its higher altitude. The average temperature and radiation of each month of the year in Tehran are shown in Figure 8. Also, the graph of average relative humidity every month in Tehran can be seen in Figure 9. Tehran has hot summers and cold and semi-arid winters. Sunshine peaks in July and January, have the least amount of solar radiation due to the short day. Energy consumption in terms of kilowatts for a house designed with the same conditions was calculated in Tehran. The calculation was performed for each month in with and without SC modes. Figure 10 shows SC has had positive results for almost all the months. Of course, due to more sunlight in summer, energy savings are greater in this season. The number of months that Summer-SC can be used is 6 (from May to October). Table 5 summarizes the results of 
energy saving by using SC for Tehran. The highest percentage of energy saving is in November (Winter-SC) and May (Summer-SC). Summer-SC and Winter-SC each, can work six months of the year. In the annual calculation, as shown in Table 6, approximately $35 \%$ of the required cooling load is reduced. On the other hand, the reduction in the heating load was about $20 \%$. Therefore, it can be concluded that the potential of SC for cooling is greater than for heating in a semiarid climate.

Table 5. Energy saved by month-Semi-Arid (Tehran)

\begin{tabular}{ccc}
\hline Month & SC Type & Percentage of energy saved \\
\hline January & Winter SC & 5 \\
February & Winter SC & 24 \\
March & Winter SC & 49 \\
April & Winter SC & 70.5 \\
May & Summer SC & 59 \\
June & Summer SC & 38 \\
July & Summer SC & 31 \\
August & Summer SC & 22 \\
September & Summer SC & 25 \\
October & Summer SC & 74 \\
November & Winter SC & 25 \\
\hline
\end{tabular}

Table 6. Annual consumption load-Semi-Arid (Tehran)

\begin{tabular}{ccc}
\hline$\#$ & $\begin{array}{c}\text { Annual cooling load requirement } \\
(\mathrm{kWh})\end{array}$ & $\begin{array}{c}\text { Annual heating load requirement } \\
(\mathrm{kWh})\end{array}$ \\
\hline With SC & 5,532 & 5,955 \\
Without SC & 8,715 & 7,469 \\
Percentage of energy saved & $35 \%$ & $20 \%$ \\
\hline
\end{tabular}

Table 7. Economic calculations over 25 years based on consumption load

\begin{tabular}{ccccc}
\hline Climate & Building mode & $\begin{array}{c}\text { Total load } \\
(\mathrm{MWh})\end{array}$ & $\begin{array}{c}\text { Electricity consumption } \\
\text { cost (Dollar) }\end{array}$ & $\begin{array}{c}\text { Cost savings } \\
\text { (Dollar) }\end{array}$ \\
\hline $\begin{array}{c}\text { Hot-Humid } \\
\text { (Babol) }\end{array}$ & With SC & 354 & 2,062 & 491 \\
photovoltaic cells & Without SC & 439 & 2,553 & 3 \\
Semi-Arid (Tehran) & With SC & 287 & 1,670 & 682 \\
\hline
\end{tabular}




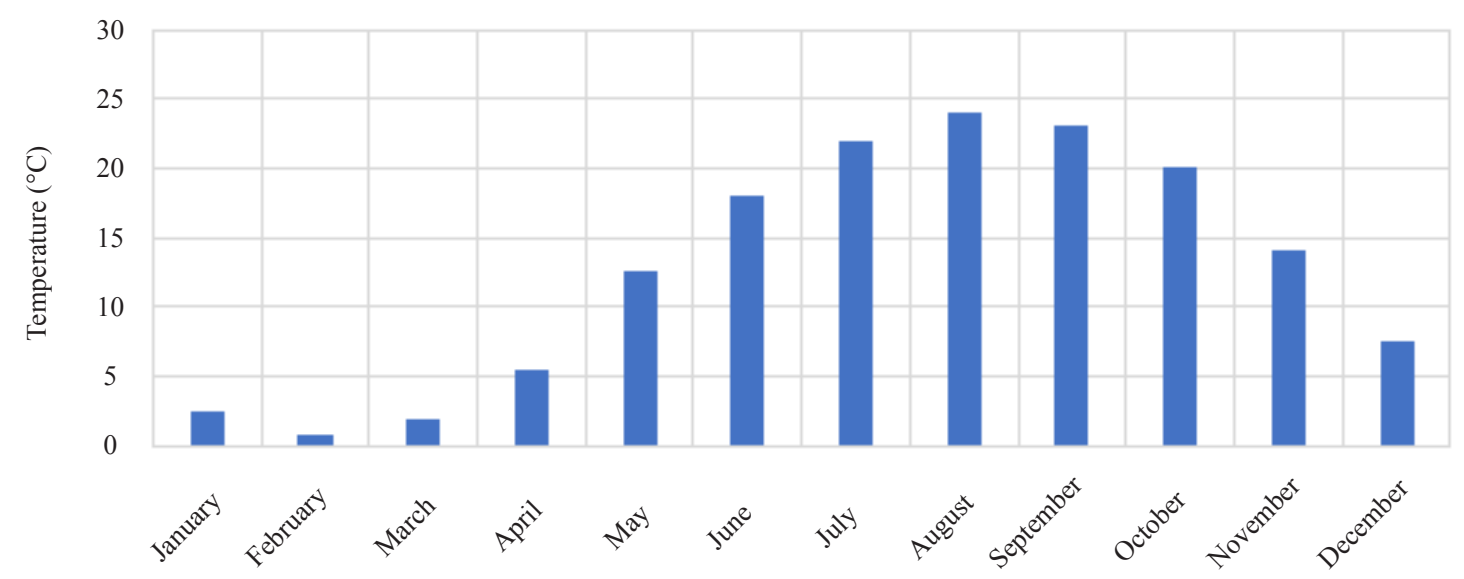

(a)

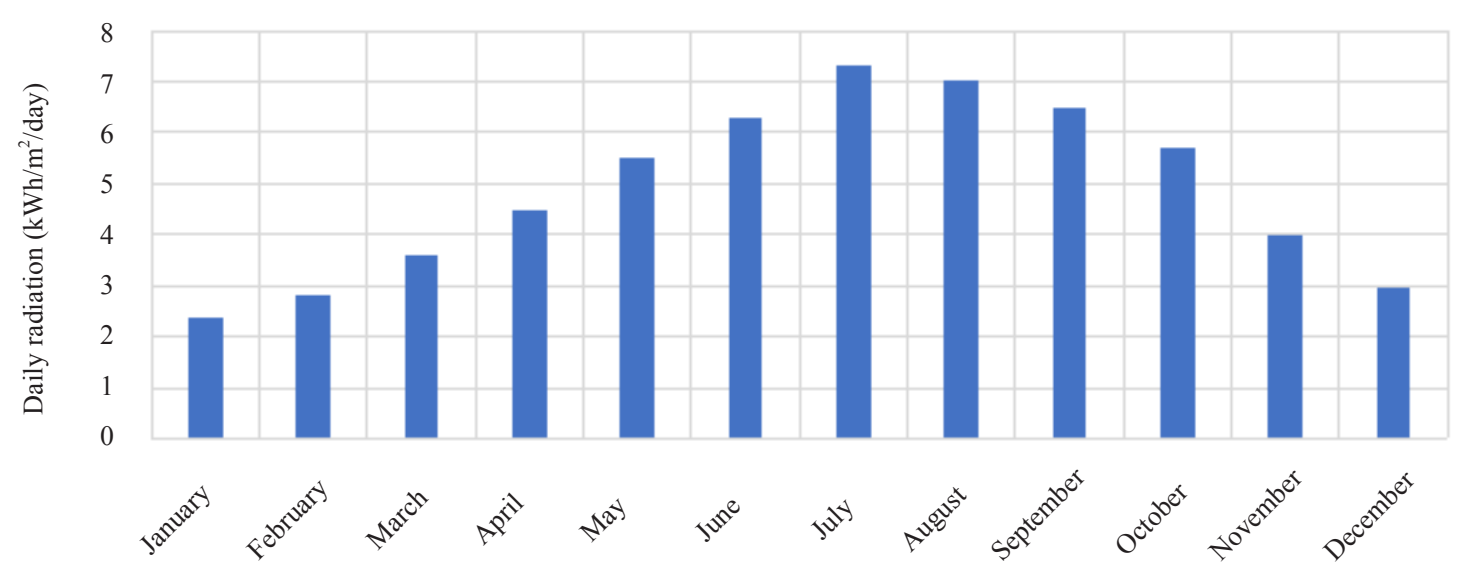

(b)

Figure 8. Average annual Temperature (a) and Radiation (b) in Tehran

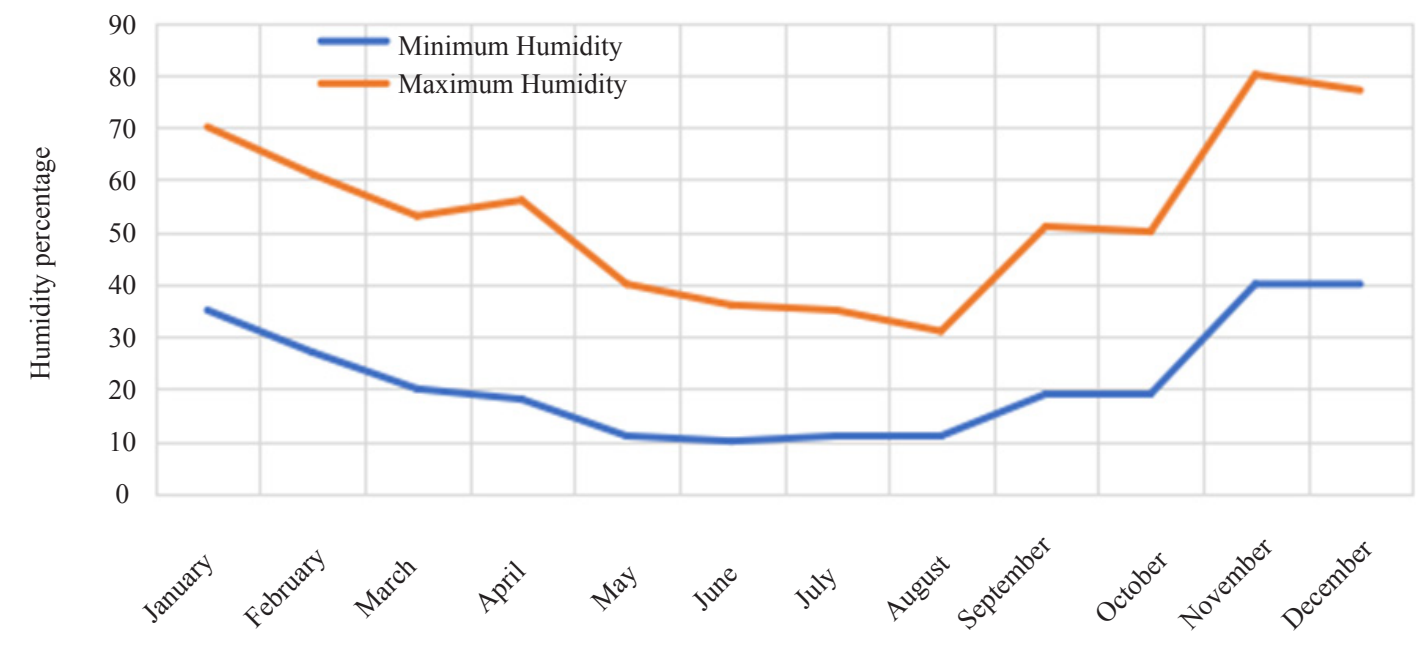

Figure 9. Graph of average relative humidity every month in Tehran 


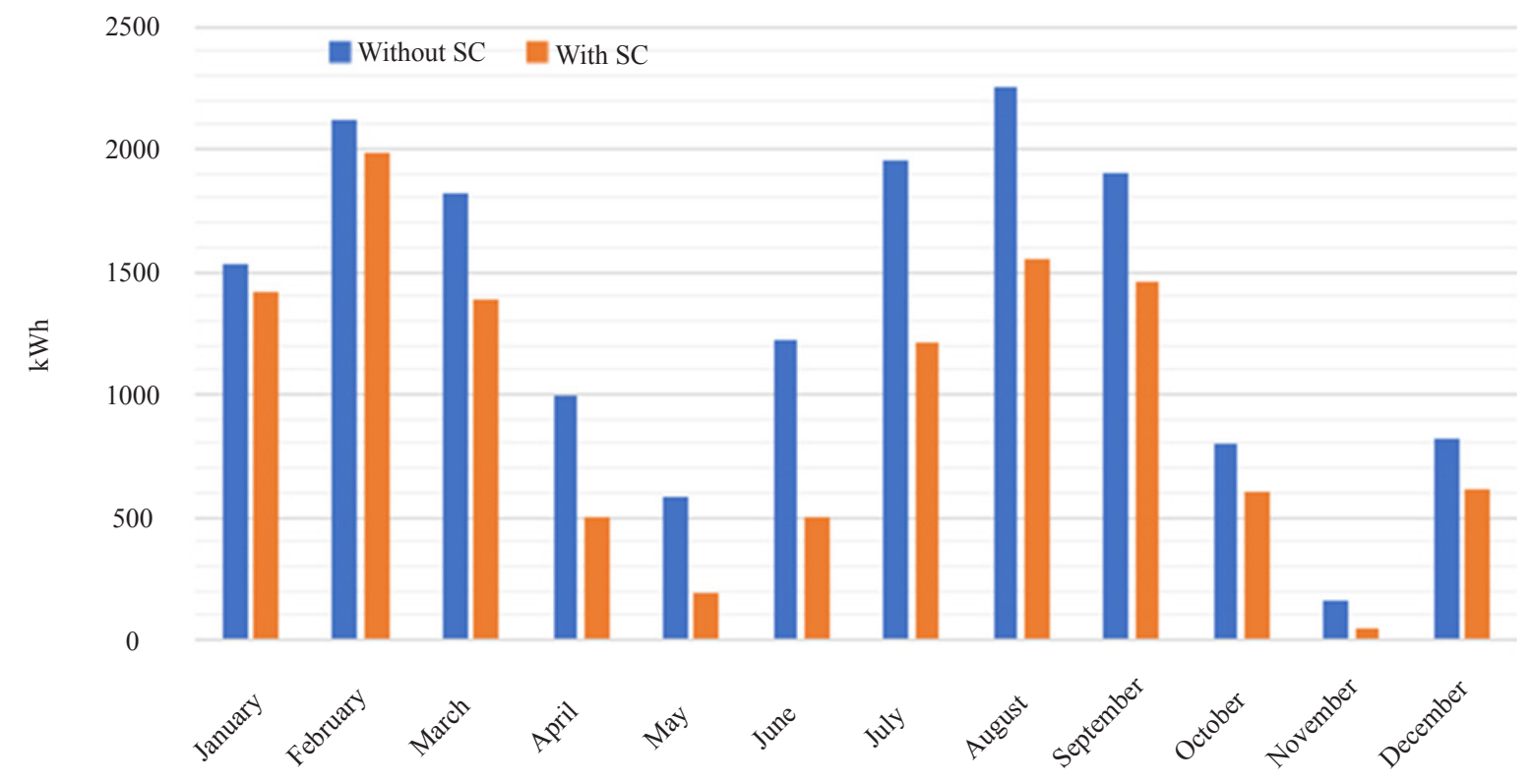

Figure 10. The amount of annual energy consumption in conditions with and without solar chimney for the city of Tehran

\subsection{Employing photovoltaic cells beside SC in the building}

According to the cost of electricity consumption per kilowatt-hour in the country, the amount of cost saved by using SC can be calculated. Table 7 shows saving electricity consumption causes a decrease of approximately 682 and 491 dollars for a house considered in Tehran and Babol during the 25 years. Calculations were performed for 25 years because the lifetime of each photovoltaic cell (PV) is 25 years. Considering the base price of PV, it was calculated that 3 PV could be provided for this house in Babol and 4 PV in Tehran. Selected PV has a capacity of 330 watts with an estimated capital of $\$ 167$. The effect of temperature on cells and efficiency were considered 0.48 and $15 \%$, respectively. The system is connected to the grid electricity to provide other required power consumption. Also, a converter was considered to convert the generated DC power to AC. A general schematic of power supply systems calculated in Homer software is shown in Figure 11. According to Table 8, combining SC and PV systems in a house with an approximate area of $250 \mathrm{~m}^{2}$ in Hot-Humid city (Babol) will produce $4717 \mathrm{kWh}$ of clean energy annually and will save $\$ 8$ in electricity costs. This is a net savings or net income (taking into account the cost of providing PV). Also, for the same house in Tehran, $6965 \mathrm{kWh}$ of clean energy will be produced annually and $\$ 14$ will be saved. If this operation is performed for all the houses in a city, the amount saved and the clean energy produced can be significant (Especially in Semi-Arid climates).

Table 8. Annual environmental and economic impact of combining SC and PV in the house

\begin{tabular}{ccc}
\hline Climate & $\begin{array}{c}\text { Clean energy produced } \\
(\mathrm{kWh})\end{array}$ & $\begin{array}{c}\text { Saved capital } \\
(\text { Dollar })\end{array}$ \\
\hline Hot-Humid (Babol) & 4717 & 8 \\
Semi-Arid (Tehran) & 6965 & 14 \\
\hline
\end{tabular}




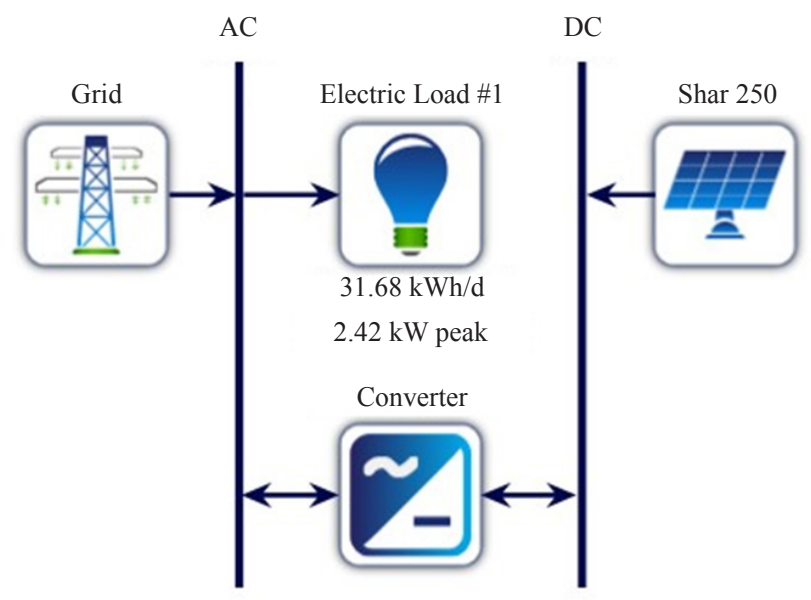

Figure 11. Design of building power supply system

\section{Conclusion}

In this study, the potential of heating and cooling consumption was calculated in two modes (with SC and without SC) for both Hot-Humid (Babol) and Semi-Arid (Tehran) climates. The simulation was performed for a house $\left(200 \mathrm{~m}^{2}\right)$ with SC on the southern, in EnergyPlus. The results show that Summer-SC reduces the cooling load by $21 \%$ and WinterSC by $16 \%$ of the heating load (Hot-Humid, Babol). On the other hand, in Tehran, using SC can save $35 \%$ in cooling load consumption and $20 \%$ in heating load consumption. So, for both Hot-Humid and Semi-Arid climates, Summer-SC performed better than Sinter-SC. Also, due to the higher temperature difference between night and day, the performance of SC in Semi-Arid climates is better than Hot-Humid climates. The cost savings were calculated by reducing the load consumption over 25 years, which equals the lifetime of photovoltaic cells. The saved cost for both cities was spent on the purchase and installation of PV panels. Then in Homer, electricity generated from the PV and grid electricity was calculated. According to calculations, SC and PV systems annually produce $4717 \mathrm{kWh}$ of clean energy in Babol and $6965 \mathrm{kWh}$ in Tehran. Also, combining these two systems in each house with this area annually reduces the cost of electricity consumption by $\$ 8$ and $\$ 14$, respectively, in the cities of Babol and Tehran.

\section{References}

[1] Arkar C, Medved S. Free cooling of a building using PCM heat storage integrated into the ventilation system. Solar Energy. 2007; 81(9): 1078-1087. Available from: doi: 10.1016/j.solener.2007.01.010.

[2] Lam JC, Yang L, Liu J. Development of passive design zones in China using bioclimatic approach. Energy Convers Manage. 2006; 47(6): 746-762. Available from: doi: 10.1016/j.enconman.2005.05.025.

[3] Xaman J, Vargas-Lopez R, Gijon-Rivera M, Zavala-Guillen I, Jimenez MJ, Arce J. Transient thermal analysis of a solar chimney for buildings with three different types of absorbing materials: copper plate/PCM/concrete wall. Renewable Energy. 2019; 136: 139-158. Available from: doi: 10.1016/j.renene.2018.12.106.

[4] Li Y, Liu S, Lu J. Effects of various parameters of a PCM on thermal performance of a solar chimney. Applied Thermal Engineering. 2017; 127(25): 1119-1131. Available from: doi: 10.1016/j.applthermaleng.2017.08.087.

[5] Frutos Dordelly JC, El Mankibi M, Roccamena L, Remion G, Arce Landa J. Experimental analysis of a PCM integrated solar chimney under laboratory conditions. Solar Energy. 2019; 188: 1332-1348. Available from: doi: 10.1016/j.solener.2019.06.065.

[6] Sardari PT, Grant D, Giddings D, Walker GS, Gillott M. Composite metal foam/PCM energy store design for dwelling space air heating. Energy Conversion and Management. 2019; 201: 112151. Available from: doi: 10.1016/ j.enconman.2019.112151.

[7] Bansal NK, Mathur R, Bhandari MS. Solar chimney for enhanced stack ventilation. Building and Environment. 1993; 28(3): 373-377. Available from: doi: 10.1016/0360-1323(93)90042-2. 
[8] Hirunlabh J, Kongduang W, Namprakai P, Khedari J. Study of natural ventilation of houses by a metallic solar wall under tropical climate. Renewable Energy. 1999; 18(1): 109-119. Available from: doi: 10.1016/S09601481(98)00783-6.

[9] Sudaporn C, Bundit L. Utilization of cool ceiling with roof solar chimney in Thailand: The experimental and numerical analysis. Renewable Energy. 2014; 34(3): 623-633. Available from: doi: 10.1016/j.renene.2008.05.026.

[10] Burek SAM, Habeb A. Air flow and thermal efficiency characteristics in solar chimneys and Trombe Walls. Energy and Buildings. 2007; 39(2): 128-135. Available from: doi: 10.1016/j.enbuild.2006.04.015.

[11] Imran AA, Jalil JM, Ahmed ST. Induced flow for ventilation and cooling by a solar chimney. Renewable Energy. 2015; 78: 236-244. Available from: doi: 10.1016/j.renene.2015.01.019.

[12] Bassiouny R, Koura NSA. An analytical and numerical study of solar chimney use for room natural ventilation. Energy and Buildings. 2008; 40(5): 865-873. Available from: doi: 10.1016/j.enbuild.2007.06.005.

[13] Sudprasert S, Chinsorranant C, Rattanadecho P. Numerical study of vertical solar chimneys with moist air in a hot and humid climate. International Journal of Heat and Mass Transfer. 2016; 102: 645-656. Available from: doi: 10.1016/j.ijheatmasstransfer.2016.06.054.

[14] Lechowska A, Szczepanik-Ścisło N, Schnotale J, Stelmach M, Pyszczek T. CFD modelling of transient thermal performance of solar chimney used for passive ventilation in a building. IOP Conference Series: Materials Science and Engineering. 2018; 415: 012049. Available from: doi: 10.1088/1757-899X/415/1/012049.

[15] Abdallah ASH. Occupant comfort and indoor temperature reduction by using passive air conditioning system with solar chimney concept in hot arid climate. Procedia Engineering. 2017; 205: 1100-1107. Available from: doi: 10.1016/j.proeng.2017.10.178.

[16] Abdeen A, Serageldin AA, Ibrahim ME, El-Zafarany A, Ookawara S, Murata R. Solar chimney optimization for enhancing thermal comfort in Egypt: An experimental and numerical study. Solar Energy. 2019; 180: 524-536. Available from: doi: 10.1016/j.solener.2019.01.063.

[17] EnergyPlus. Available from: https://energyplus.net/ [Accessed 27th October 2020].

[18] Berkeley L, Ridge OAK, Ut-battelle MBY. For, A., Energy, S., Or, D., In, T., Form, A. N. Y., By, O. R., Means, A. N. Y., \& The, W. Engineering Reference. 2019.

[19] Chungloo S, Limmeechokchai B. Application of passive cooling systems in the hot and humid climate: The case study of solar chimney and wetted roof in Thailand. Building and Environment. 2007; 42(9): 3341-3351. Available from: doi: 10.1016/j.buildenv.2006.08.030.

[20] Arce J, Jiménez MJ, Guzmán JD, Heras MR, Alvarez G, Xamán J. Experimental study for natural ventilation on a solar chimney. Renewable Energy. 2009; 34(12): 2928-2934. Available from: doi: 10.1016/j.renene.2009.04.026.

[21] Jiménez MJ, Guzmán J, Heras MR, Arce J, Xamán JP, Alvarez G. Thermal performance of a natural ventilation system. In: Proceedings of the ASME 4th International Conference on Energy Sustainability, Phoenix, AZ, USA. 2010. p. 329-336.

[22] Suite S, Co B. HOMER ${ }^{\circledR}$ Pro Version 3.7 User Manual $^{\odot}$ All rights reserved. August 2016 HOMER $^{\circledR}$ Energy Boulder CO 80301 USA. Available from: https://www.homerenergy.com/pdf/HOMERHelpManual.pdf [Accessed August 2016].

[23] Garrett A, New JR. Suitability of ASHRAE Guideline 14 Metrics for Calibration. Available from: http://web.eecs. utk.edu/ jnew1/publications/2016_ASHRAE_G14.pdf [Accessed January 2016]. 